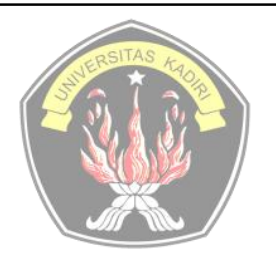

Tersedia online di

"http://ojs.unik-kediri.ac.id/index.php/ekonika"

http://dx.doi.org/10.30737/ekonika.v6i1.1454

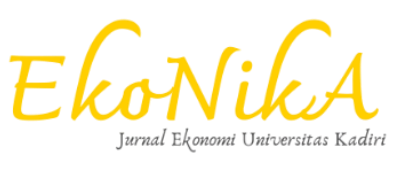

\title{
Menjaga Eksistensi Usaha Mikro, Kecil, dan Menengah Pada Masa
}

\section{Pandemi Covid-19}

\author{
Ni Nyoman Sri Rahayu Damayanti ${ }^{1}$ \\ ${ }^{1}$ Fakultas Ekonomi dan Bisnis Universitas Warmadewa \\ email: ${ }^{1}$ rahayudamayanti8@gmail.com
}

Artikel History:

Artikel masuk : 2 februari 2011

Artikel revisi : 10 maret 2021

Artikel diterima : 28 maret 2021

\section{Keywords:}

MSMEs, Government Policy, Covid-19 Pandemi

\begin{abstract}
ABSTRAK
Usaha Mikro, Kecil, dan Menengah (UMKM) merupakan usaha yang mampu membangun perekonomian nasional berdasarkan demokrasi ekonomi yang berkeadilan. Operasional UMKM sangat dipengaruhi salah satunya oleh kondisi pasar. Kondisi pasar menjadi tidak menentu sejak terjadi pandemi Covid-19. UMKM menjadi salah satu usaha yang turut merasakan dampak tersebut. UMKM dianggap memiliki daya tahan yang rendah serta tingkat fleksibilitas yang rendah dalam menghadapi situasi pandemi. UMKM dinilai kurang memiliki ketahanan dan fleksibilitas dalam menghadapi pandemi ini dikarenakan beberapa hal seperti tingkat digitalisasi yang masih rendah, kesulitan dalam mengakses teknologi dan kurangnya pemahaman tentang strategi bertahan dalam bisnis. Berdasarkan atas permasalahan tersebut, penting untuk dilakukan berbagai tindakan berupa kebijakan-kebijakan untuk menyelamatkan keberlangsungan UMKM di tengah kondisi pandemi. Penelitian ini menggunakan metode kualitatif deskriptif. Berdasarkan atas kajian literatur yang dilakukan, maka terdapat beberapa kebijakan yang dirumuskan oleh pemerintah untuk menjaga eksistensi UMKM di masa pandemi Covid-19. Kebijakan tersebut berikaitan dengan pemberian bantuan langsung kepada UMKM, melakukan restruktrisasi kredit, memberikan insentif pajak, pemberian kredit modal kerja, melakukan pembelian produk UMKM, mengimplementasikan protokol kesehatan di dunia usaha, serta melakukan digitalisasi UMKM.
\end{abstract}

\begin{tabular}{l} 
ABSTRACT \\
\hline Micro, Small and Medium Enterprises (MSMEs) are \\
businesses that capable of building a national economybased \\
on equitable economic democracy. MSME operations are \\
strongly influenced by market conditions. Market conditions \\
have become uncertain since the Covid-19 pandemi. MSMEs \\
are one of the businesses that also feel the impact. MSMEs \\
are considered to lack resilience and flexibility in dealing
\end{tabular}

Menjaga Eksistensi Usaha Mikro, Kecil, dan Menengah Pada Masa Pandemi Covid-19

(c) 2021 Ekonika : Jurnal Ekonomi Universitas Kadiri. Semua hak cipta dilindungi undang-undang 
with this pandemi due to several things such as low digitization capability, difficulty in accessing technology and lack of understanding of defensive strategies in business. Based on these problems, it is important to take various actions in the form of policies to save the sustainability of MSMEs in the midst of pandemi conditions. This research uses descriptive qualitative method. Based on the literature review conducted, there are several policies formulated by the government to maintain the existence of MSMEs during the Covid-19 pandemi. The policy is related to providing direct assistance to MSMEs, loan restructuring, providing tax incentives, providing working capital loan, purchasing MSME products, implementing health protocols in the business world, and digitizing MSMEs.

\section{INTRODUCTION}

Usaha Mikro, Kecil, dan Menengah (UMKM) merupakan usaha produktif yang didirikan oleh seseorang yang melakukan berbagai kegiatan ekonomi. Undang-Undang Nomor 20 Tahun 2008 merupakan salah satu peraturan yang didalamnya mengatur mengenai UMKM secara terperinci. UMKM berperan dalam membangun perekonomian nasional yang berasakan pada demokrasi ekonomi yang berkeadilan. Pemerintah melakukan berbagai upaya untuk menciptakan iklim usaha yang kondusif bagi UMKM agar menjadi usaha yang tangguh dan mandiri. Salah satu upaya yang dilakukan pemerintah untuk memberdayakan UMKM adalah dengan membentuk berbagai peraturan perundang-undangan dan kebijakan. Hal tersebut dilakukan pemerintah dengan tujuan agar UMKM memiliki kepastian dan perlindungan hukum serta dukungan untuk terus mengembangkan usahanya. Operasional UMKM sangat dipengaruhi salah satunya oleh kondisi pasar. Kondisi pasar menjadi tidak menentu sejak terjadi pandemi Covid-19. Pandemi memberikan pengaruh negatif pada berbagai sector terutama sektor ekonomi. Laporan Organization for Economic Cooperation and Development (OECD) menyatakan bahwa pandemi Covid 19 dapat menyebabkan krisis ekonomi yang ditandai dengan terhambatnya aktivitas perekonomian di beberapa negara. Selain itu, pandemi telah meyebabkan rendahnya tingkat konsumsi masyarakat serta menimbulkan ketidakpastian pada bursa saham suatu negara (OECD, 2020). UMKM menjadi salah satu usaha yang turut merasakan dampak tersebut. Hal tersebut terjadi karena UMKM merupakan sector usaha yang memiliki posisi strategis dalam perekonomian suatu negara. Di ASEAN, UMKM mampu menciptakan lapangan pekerjaan dengan persentase antara 50\% sampai dengan 95\%. UMKM juga telah berkontribusi sebanyak 30\% sampai dengan 50\% pada Gross Domestic Product (Islam, 2020). Krisis ini akan berdampak pada ketidakmampuan UMKM untuk bertahan. 
Sulitnya situasi keuangan yang dihadapi oleh UMKM dapat menyebabkan efek sistemik pada sector lainnya, salah satunya adalah sektor perbankan (OECD, 2020).

Berdasarkan data yang tercatat pada Kementerian Koperasi dan Usaha Kecil dan Menengah Republik Indonesia, pada tahun 2018 jumlah UMKM di Indonesia mencapai 64.194.057 UMKM. Jumlah UMKM mengalami peningkatan sebesar 2,02\% dari tahun 2017 sampai dengan tahun 2018. Jumlah penyerapan tenaga kerja pada UMKM tahun 2018 sebesar 116.978.631 jiwa. Jumlah ini meningkat sebesar 0,47\% dari tahun 2017 (Kemenkopukm, 2020). Adanya penyerapan tenaga kerja dengan jumlah yang cukup tinggi, turut berkontribusi dalam menekan jumlah pengangguran di Indonesia. Berdasarkan atas survey yang dilakukan oleh Bank Indonesia, terdapat 72\% UMKM yang mengalami dampak atas pandemi Covid-19. Sektor pertanian, ekspor, dan keranjinan merupaka sektor usaha yang dianggap paling terdampak pandemi. Hal serupa juga diungkapkan pada penelitian OECD (2020) dan Febrantara (2020) yang menyatakan bahwa sektor pariwisata dan transportasi adalah sector yang paling terdampak kondisi pandemi. Adapun beberapa kesulitan yang dialami oleh UMKM yaitu terjadinya penurunan penjualan, kesulitan permodalan, terhambatnya proses distribusi produk, kesulitan bahan baku, penurunan produksi serta pemutusan hubungan kerja pada tenaga kerja. UMKM kini sedang mengalami penurunun tingkat produktivitas yang dapat berpengaruh pada penurunan profit usaha. Penurunan profit juga disebabkan akibat rendahnya daya beli konsumen. Rendahnya daya beli konsumen salah satunya dipengaruhi oleh tingkat prioritas masyarakat yang kini cenderung untuk melakukan tindakan saving money akibat ketidakpastian yang disebabkan oleh pandemi. UMKM dianggap memiliki daya tahan yang rendah serta tingkat fleksibilitas yang rendah dalam menghadapi situasi pandemi. Hal tersebut disebabkan oleh rendahnya tingkat digitalisasi, tingginya tingkat kesulitan dalam mengakses teknologi, serta rendahnya tingkat pemahaman UMKM mengenai strategi bertahan dalam bisnis (OECD, 2020). Berdasarkan atas permasalahan tersebut, penting untuk dilakukan berbagai tindakan berupa kebijakan-kebijakan untuk menyelamatkan keberlangsungan UMKM di tengah konsisi pandemi.

Penelitian ini dilakukan untuk mendeskripsikakan tindakan pemerintah yang dilakukan untuk menyelamatkan keberlangsungan UMKM dalam masa pandemi di Indonesia. Tindakan pemerintah dapat berupa kebijakan dan strategi yang dirumuskan untuk memperkuat operasional UMKM. Penelitian ini memiliki unsur kebaharuan karena akan mendeskripsikan mengenai kebijakan dan strategi terbaru akibat fenomena pandemi Covid-19. Berdasarkan atas latar belakang tersebut, adapun rumusan masalah pada penelitian ini yaitu bagaimana kebijakan pemerintah bagi UMKM dalam menghadapi pandemi Covid-19?. 


\section{LITERATURE REVIEW}

\section{Usaha Mikro, Kecil, dan Menengah}

Undang-Undang Nomor 20 tahun 2008 merupakan peraturan yang didalamnya mengatur tentang UMKM. Berdasarkan UU Nomor 20 tahun 2008, usaha mikro, kecil, dan menengah yang selanjutnya disingkat sebagai UMKM didefinisikan sebagai berikut.

a. Usaha mikro adalah usaha produktif milik orang perorangandan/atau badan usaha perorangan yang memenuhi kriteriaUsaha Mikro sebagaimana diatur dalam UndangUndang. Kriteria usaha mikro adalah memiliki kekayaan bersih paling banyak Rp. 50.000.000,00, tidak termasuk tanah dan bangunan tempat usaha atau memiliki hasil penjualan tahunan paling banyak Rp300.000.000,00.

b. Usaha Kecil adalah usaha ekonomi produktif yang berdiri sendiri, yang dilakukan oleh orang perorangan atau badan usaha yang bukan merupakan anak perusahaan atau bukan cabang perusahaan yang dimiliki, dikuasai, atau menjadi bagian baik langsung maupun tidak langsung dari Usaha Menengah atau Usaha Besar. Kriteria usaha kecil adalah memiliki kekayaan bersih lebih dari Rp 50.000.000,00 sampai dengan paling banyak Rp 500.000.000,00 tidak termasuk tanah dan bangunan tempat usaha atau memiliki hasil penjualan tahunan lebih dari Rp300.000.000,00 sampai dengan paling banyak Rp 2.500.000.000,00.

c. Usaha Menengah adalah usaha ekonomi produktif yang berdiri sendiri, yang dilakukan oleh orang perorangan atau badan usaha yang bukan merupakan anak perusahaan atau cabang perusahaan yang dimiliki, dikuasai, atau menjadi bagian baik langsung maupun tidak langsung dengan Usaha Kecil atau Usaha Besar dengan jumlah kekayaan bersih atau hasil penjualan tahunan sebagaimana diatur dalam Undang-Undang. Kriteria usaha menengah adalah memiliki kekayaan bersih lebih dari Rp500.000.000,00 sampai dengan paling banyak Rp10.000.000.000,00 tidak termasuk tanah dan bangunan tempat usaha; atau b.memiliki hasil penjualan tahunan lebih dari Rp2.500.000.000,00 sampai dengan paling banyak Rp50.000.000.000,00.

\section{METHOD}

Penelitian ini dilaksanakan dengan metode kualitatif deskriptif. Metode tersebut akan menghasilkan data dalam bentuk deskriptif berupa kata tertulis atau lisan yang berasal dari seseorang atau dari perilaku serta peristiwa yang dapat diamati (Maleong, 2011:4). Nawawi 
dan Martini (1994:73) menyatakan bahwa metode kualitatif deskriptif merupakan metode yang menggambarkan suatu keadaan yang bersifat objektif. Metode tersebut juga digunakan untuk menggambarkan suatu peristiwa terstentu berdasarkan fakta atau sebagaimana mestinya yang kemudian diikuti dengan upaya pengambilan kesimpulan. Penelitian ini menggunakan data sekunder yang berasal dari berbagai literatur yaitu buku, artikel ilmiah, peraturan perundangundangan, serta artikel yang bersumber dari website resmi pemerintah. Data yang telah diperoleh akan dideskripsikan secara terperinci pada bagian pembahasan. Penelitian ini merupakan penelitian pustaka yang memusatkan perhatian pada kebijakan pemerintah bagi UMKM dalam menghadapi pandemi Covid-19 serta strategi penunjang yang dapat digunakan untuk mendukung kebijakan pemerintah.

\section{RESULT}

\section{Pertumbuhan UMKM di Indonesia}

UMKM merupakan usaha yang memiliki peran strategis dalam perekonomian Indonesia. Jumlah UMKM dari tahun ke tahun selalu mengalami peningkatan.. Adapun jumlah UMKM di Indonesia dari tahun 2015 sampai dengan tahun 2018 ditunjukan pada Gambar 1.

\section{Gambar 1. Pertumbuhan UMKM di Indonesia Tahun 2015-2018}

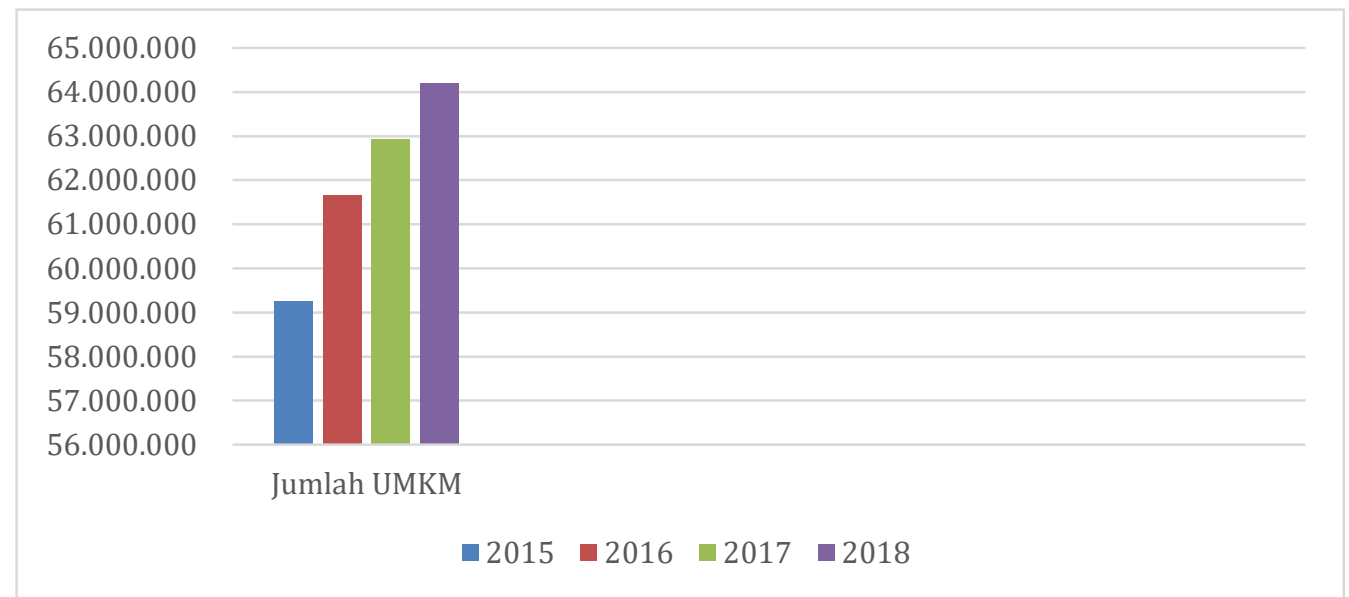

Sumber: Kementerian Koperasi dan Usaha Kecil dan Menengah RI, 2020

Pada tahun 2015, jumlah UMKM di Indonesia adalah sebesar 59.262.772 unit. Pada tahun 2016 mengalami peningkatan menjadi 61.651 .177 unit. Begitu pula pada tahun 2017 dan tahun 2018 meningkat berturut-turut sejumlah 62.922.617 dan 64.194.057 unit. Peningkatan jumlah UMKM tidak diikuti dengan peningkatan penyerapan jumlah tenaga kerja oleh UMKM. Adapun jumlah penyerapan tenaga kerja UMKM ditampilkan pada Gambar 2. 


\section{Gambar 2. Penyerapan Tenaga Kerja oleh UMKM}

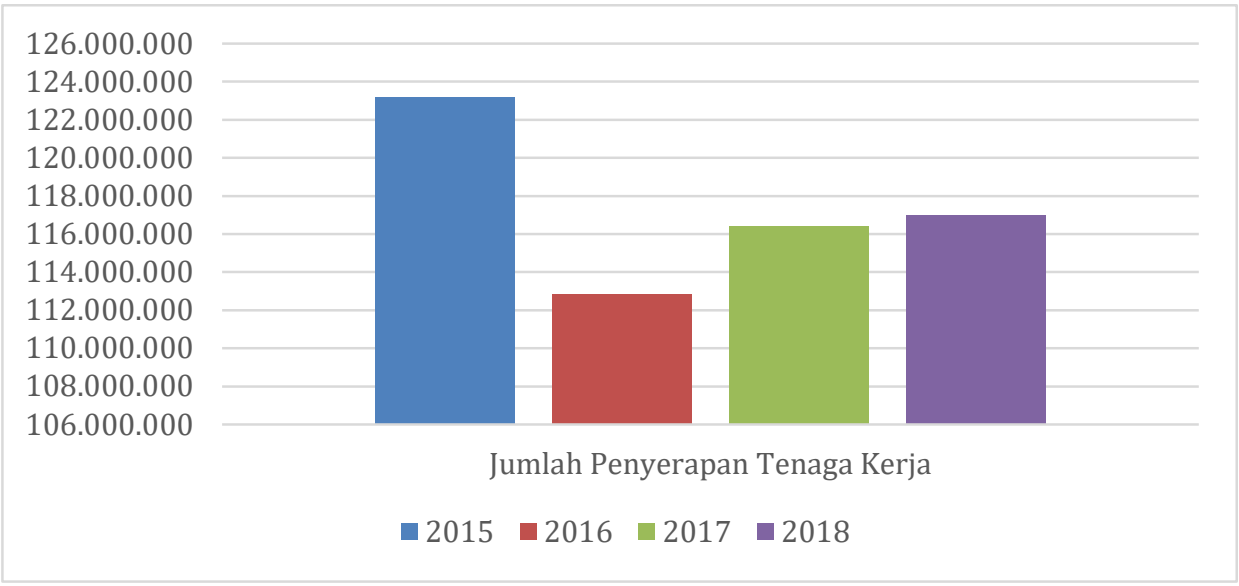

Sumber: Kementerian Koperasi dan Usaha Kecil dan Menengah RI, 2020

Gambar 2 menunjukan bahwa jumlah penyerapan tenaga kerja oleh UMKM di Indonesia mengalami fluktuasi dari tahun ke tahun. Pada tahun 2015, jumlah penyerapan tenaga kerja paling tinggi diantara empat tahun terakhir yaitu sejumlah 123.229.387 jiwa. Pada tahun 2016 terjadi penurunan cukup drastis dengan jumlah penyerapan sebesar 112.828.610. Pada tahun 2017 dan 2018 terjadi peningkatan pada penyerapan tenaga kerja yaitu sejumlah 116.431.224 dan 116.978.631 jiwa. Pentingnya peran UMKM membuat pemerintah harus membuat kebijakan guna membantu UMKM dalam menghadapi pandemi.

\section{Permasalahan UMKM Pada Masa Pandemi Covid-19}

Berbagai permasalahan dialami UMKM selama masa pandemi. Sampai dengan Agustus 2020, terdapat 300.000 pelaku UMKM terdampak Covid-19 yang telah membuat laporan kepada Kementerian Koperasi dan UKM (Catriana, 2020). Berdasarkan atas data dari Kementrian Koperasi dan UKM RI, terdapat empat permasalahan utama yang dialami UMKM yaitu sebagai berikut.

1. Penurunan Penjualan

Terdapat 57\% UMKM melakukan pelaporan kepada Kementrian Koperasi dan UMKM telah mengalami penurunan penjualan. Penurunan penjualan terjadi akibat rendahnya daya beli konsumen. Pandemi menyebabkan jumlah tenaga kerja berkurang. Selain itu, pandemi juga menyebabkan sejumlah tenaga kerja mengalami pemotongan pendapatan. Kondisi tersebut menyebabkan daya beli masyarakat semakin rendah terutama pada kategori pekerja informal dan pekerja harian. Sebagian besar masyarakat cenderung lebih mengontrol pengeluaran akibat ketidakpastian yang ditimbulkan oleh pandemi. 
Hal tersebut menyebabkan daya beli masyarakat khususnya pada barang konsumsi semakin menurun. Kondisi tersebut akan memberikan tekanan bagi pelaku bisnis yaitu produsen dan penjual barang konsumsi (Pakpahan, 2020).

2. Kesulitan Permodalan

Terdapat 22\% UMKM melakukan pelaporan bahwa telah mengalami kesulitan permodalan. Kesulitan permodalan dialami UMKM sejak sebelum pandemi dan bertambah lebih buruk setelah pandemi terjadi. Pada umumnya UMKM menghadapi permasalahan modal kerja dan modal investasi (Hartono dan Hartomo, 2014).

3. Hambatan Distribusi Produk

Terdapat 15\% UMKM melaporkan mengalami kesulitan dalam melaksanakan distribusi produk. Hal ini salah satunya disebabkan oleh kebijakan social distancing dan pembatasan sosial berskala besar (PSBB) yang dilakukan di berbagai daerah (Kusumastuti, 2020).

4. Kesulitan Bahan Baku

Terdapat 4\% UMKM mengalami hambatan dalam memperoleh bahan baku yang digunakan dalam proses produksi. Kendala ini juga terkait dengan dilaksanakannya Pembatasan Sosial Berskala Besar (PSBB) sscds ddsddddscsscds ddsddddsc

AA9a 9 ozy12fwgb7yfgv jnjjjjjj byang diterapkan di beberapa daerah. PSBB dilaksanakan untuk mencegah perluasan penyebaran Covid-19 (Pakpahan, 2020). Hal ini tentu akan menghambat proses distribusi termasuk distribusi bahan baku.

\section{Kebijakan Pemerintah Bagi UMKM Pada Masa Pandemi Covid 19}

Pemerintah kini sedanga melakukan program Pemulihan Ekonomi Nasional (PEN). Pemerintah membuat beberapa kebijakan terkait penyelamatan UMKM dalam usaha melakukan perbaikan ekonomi nasional pada masa pandemi. Adapun kebijakan tersebut yaitu sebagai berikut.

\section{Bantuan Langsung}

Bantuan ini diberikan untuk meringankan biaya yang harus dikeluarkan oleh UMKM. Salah satu bantuan langsung yang dicetuskan pemerintah adalah Banpres Produktif Usaha Mikro. Bantuan ini merupakan salah satu strategi yang dilakukan oleh pemerintah agar usaha mikro mampu bertahan di dalam kondisi pandemi. Banpres diusulkan oleh Dinas Koperasi dan UKM. Program ini selain melibatkan Dinas Koperasi dan UKM, juga melibatkan Koperasi yang 
telah disahkan sebagai Badan Hukum, Kementerian, perbankan dan perusahaan pembiayaan yang terdaftar di Otoritas Jasa Keuangan (OJK). Banpres produktif merupakan dana hibah, bukan dana pinjaman yang diberikan kepada usaha mikro. Pada proses penyaluran bantuan langsung, para penerima tidak akan dipungut biaya apapun.

\section{Restrukturisasi Kredit}

Restrukturisasi kredit UMKM merupakan strategi yang dilakukan oelh pemerintah agar UMKM yang memiliki kredit dapat mengajukan penundaan pembayaran pokok serta mendapatkan subsidi. Kebijakan ini diatur dalam Peraturan Menteri Keuangan Nomor 65/PMK.05/2020 mengenai Tata Cara Pemberian Subsidi Bunga/Subsidi Margin untuk Kredit/Pembiayaan Usaha Mikro, Kecil, dan Menengah. Peraturan ini dibuat dalam rangka mendukung pelaksanaan program pemulihan ekonomi nasional. Peraturan tersebut kemudian diperbaharui dengan peraturan Nomor 85/PMK.05/2020 (Purwanto, 2020). Program ini dilaksanakan dengan melakukan kerja sama dengan Otoritas Jasa Keuangan dan Bank Indonesia. Program ini dilakukan dengan memberikan relaksasi penilaian kualitas aset, penundaan pembayaran angsuran pokok kredit serta pemberian subsidi bunga. Salah satu program subsidi bunga yang dilaksanakan Kementrian Koperasi dan UKM adalah dengan memberikan Subsidi Bunga Non-KUR. Subsidi tersebut merupakan bentuk keringanan yang diberikan kepada debitur kredit pembiayaan diluar Kredit Usaha Rakyat (KUR). Subsidi ini disebut sebagai kredit produktif. Pihak perbankan dan perusahaan pembiayaan dapat menyalurkan kredit produktif kepada UMKM yang mengalami kesulitan permodalan di masa pandemi (Kemenkopukm, 2020).

\section{Insentif Pajak}

Peraturan Menteri Keuangan (PMK) nomor 86 tentang Insentif Pajak Untuk Wajib Pajak Terdampak Pandemi, dikeluarkan oleh Menteri Keuangan guna membantu pemulihan ekonomi nasional. Kebijakan ini berupa PPh Final UMKM ditanggung oleh pemerintah. Wajib pajak diharuskan untuk menyampaikan laporan realisasi PPh final setiap bulannya. Insentif ini diberikan oleh pemeritah darimasa pajak bulan April sampai dengan bulan Desember 2020. Penerima insentif adalah UMKM yang merupakan wajib pajak yang memiliki nilai peredaran bruto tertentu dan dikenai PPh sesuai dengan PP Nomor 23 Tahun 2018 (www.pajak.go.id).

\section{Kredit Modal Kerja bagi UMKM}

Pemberian kredit modal kerja diatur dalam Peraturan Menteri Keuangan Nomor 104/PMK.05/2020. Peraturan ini mengatur pemberian modal kerja khususnya UMKM dalam 
rangka percepatan pemulihan ekonomi. Pada pelaksanaanya, pemerintah menempatkan sejumlah dana pada bank umum mitra dengan bunga tertentu. Bank Umum Mitra kemudian menggunakan dana tersebut untuk disalurkan dalam bentuk kredit atau pembiayaan kepada para pemilik usaha untuk mengembangkan UMKM miliknya (www.depkop.go.id, 2020) Pemberian kredit modal kerja ini dapat membantu keuangan UMKM agar tetap likuid

\section{Mendorong Konsumsi Produk UMKM}

Kementrian Koperasi dan UKM melakukan kerja sama dengan Lembaga Kebijakan Pengadaan Barang/Jasa Pemerintah (LKPP) untuk meningkatkan konsumsi produk yang dihasilkan oleh UMKM di Indonesia. Pemerintah telah mempersiapkan Rp. 735 triliun anggaran belanja pada tahun 2020 untuk membeli produk hasil UMKM di Indonesia (www.depkop.go.id, 2020). Program ini diharapkan mampu meningkatkan penjualan UMKM sehingga akan berkontribusi positif pada peningkatan penjualannya.

\section{Penerapan Protokol Kesehatan}

Situasi pandemi membuat UMKM harus mampu beradaptasi dengan kondisi baru. Guna menumbuhkembangan kepercayaan masyarakat, UMKM harus mengedepankan pada pelaksanakan protokol kesehatan dalam melakukan operasional usahanya. Selain untuk mencegah mata rantai penularan Covid-19, hal tersebut juga digunakan untuk memastikan bahwa UMKM peduli pada permasalahan kesehatan di Indonesia. Menteri Kesehatan Republik Indonesia membuat peraturan yang mengatur tentang penerapan protocol kesehatan bagi dunia usaha. Peraturan Nomor HK.02.01/MENKES/335/2020 tentang Protokol Pencegahan Penularan COVID-19 di Tempat Kerja Sektor Jasa dan Perdagangan (Area Publik) menyebutkan sektor jasa dan perdagangan harus tetap memperhatikan aspek kesehatan dalam melakukan upaya pencegahan dan pengendalian Covid-19 pada tempat kerja perkantoran dan industry usaha. Tempat usaha wajib menyediakan fasilitas yang berhubungan dengan protokol kesehatan (kemkes.go.id, 2020).

\section{Digitalisasi UMKM}

Kemenkop dan UKM kini tengah berupaya mendukung digitalisasi UMKM. Pemeintah menjalin kerjasama dengan aplikasi belanja daring di Indonesia untuk menganjurkan UMKM melakukan penjualan pada aplikasi tersbut. Kemenkop dan UKM menyatakan bahwa hanya sebesar $13 \%$ pelaku UMKM yang telah menerapkan digitalisasi pada usahanya. Terdapat beberapa UMKM yang telah memiliki platform digital seperti sayurbox, ekosis, tanihub, dan modal rakyat. Program digitalisasi UMKM yang dicetuskan pemerintah diharapkan mampu 
Kemenkop dan UKM telah melakukan kerja sama untuk membuat brosur elektronik dengan Smesco Indonesia. Brosur elektronik ini diharapkan mampu memasrkan produk hasil produksi UMKM secara daring. Selanjutnya, pemerintah memiliki target untuk membuat katalog produk seluruh UMKM pada portal tersebut. Digitalisasi dapat membuat transaksi terus berjalan tanpa harus melakukan interaksi secara fisik. Guna menyukseskan program tersebut, pemerintah dapat bekerja sama dengan BUMN, BUMD ataupun perusahaan ekspedisi untuk melakukan pengiriman produk UMKM (Sugiri, 2020).

\section{CONCLUSION AND SUGGESTION}

Pandemi Covid-19 tergolong dalam kejadian luar biasa yang tidak mampu diprediksi. UMKM merupakan salah satu usaha yang turut merasakan dampak negatif dari pandemi. Berbagai upaya berupa kebijakan-kebijakan dirumuskan oleh pemerintah untuk menjaga eksistensi UMKM. Adapun kebijakan tersebut berupa pemberian bantuan langsung kepada UMKM, melakukan restruktrisasi kredit, memberikan insentif pajak, pemberian kredit modal kerja, melakukan pembelian produk UMKM, mengimplementasikan protokol kesehatan di dunia usaha, serta melakukan digitalisasi UMKM. Saran penelitian selanjutnya dapat meneliti dengan mengambil sampel UMKM di suatu daerah. Setelah itu peneliti dapat melakukan observasi secara mendalam mengenai kondisi UMKM tersebut selama pandemi Covid-19.

\section{BIBLIOGRAPHY}

Catriana, E. (2020, Agustus 12). Kompas. Retrieved from Kompas: https://money.kompas.com/read/2020/08/12/050707126/kemenkop-terima-300000laporan-umkm-terpukul-pandemi-covid-19

Febrantara, D. (2020). Bagaimana Penanganan UKM di Berbagai Negara Saat Ada Pandemi Covid-19? DDTC Fiscal Research. Retrieved from https://drive.google.com/drive/folders/1MY31IOC3gWq-EgzNkuJzqJnB9PV6qA2D

Gitiyarko, V. (2020, Agustus 31). Kompas. Retrieved from Kompas: https://kompaspedia.kompas.id/baca/paparan-topik/kebijakan-perlindungan-danpemulihan-umkm-di-tengah-pandemi-covid-19

Handoko, L. T. (2020, November 11). Lembaga Ilmu Pengetahuan Indonesia. Retrieved from Lembaga Ilmu Pengetahuan Indonesia: http://lipi.go.id/siaranpress/membangkitkanumkm-di-masa-pandemi-dengan-inovasi-dan-teknologi/22212

Hartono, \& Hartomo, D. D. (2014). Faktor-Faktor Yang Mempengaruhi Perkembangan Umkm Di Surakarta. Jurnal Bisnis dan Manajemen Volume 14 Nomor 1, 15-30. 
Hendartyo, M. (2020, Juni 25). Tempo. Retrieved from Tempo: https://bisnis.tempo.co/read/1357762/survei-bi-72-persen-pelaku-umkm-terdampakpandemi-corona

Islam, A. (2020). Configuring a Quadruple Helix Innovation Model (QHIM) based blueprint for Malaysian SMEs to survive the crises happening by Covid-19. Emerald Open Res, 2.

Kemenkes. (2020). Surat Edaran No. HK.02.01/MENKES/335/2020 tentang Protokol Pencegahan Penularan COVID-19 di Tempat Kerja Sektor Jasa dan Perdagangan (Area Publik) dalam Mendukung Keberlangsungan Usaha. Jakarta

Kemenkopukm. (2020, Agustus 25). Kementerian Koperasi dan Usaha Kecil dan Menengah. Retrieved from Kementerian Koperasi dan Usaha Kecil dan Menengah: http://www.depkop.go.id/read/program-banpres-produktif-untuk-usaha-mikro

Kusumastuti, A. D. (2020). Pengaruh Pandemi Covid-19 terhadap Eksistensi Bisnis UMKMdalam mempertahankan Business Continuity Management (BCM). eJournal Administrasi Bisnis, Volume 8, Nomor 3, 224-232.

OECD. (2020). SME Policy Responses: Tackling Coronavirus (Covid-19) Contributing to A Global Effort. Retrieved from https://oecd.dam-broadcast.com/pm_7379_119_119680di6h3qgi4x.pd

Pakpahan, A. K. (2020). COVID-19 dan Implikasi Bagi Usaha Mikro, Kecil, dan Menengah. Jurnal Ilmiah Hubungan Internasional, 59-64.

Purwanto, N. P. (2020). Bantuan Fiskal Untuk UMKM Pada Masa Pandemi Covid-19. Info Singkat, 19-24.

Sugiri, D. (2020). Menyelamatkan Usaha Mikro, Kecil dan Menengah dari Dampak Pandemi Covid-19. Fokus Bisnis: Media Pengkajian Manajemen dan Akuntansi, 76-86. 